\title{
EVALUATION OF BLOOD PARAMETERS, SERUM MINERALS PROFILES AND RUMEN FERMENTATION IN DAIRY COWS WITH FOREIGN BODY SYNDROME IN SUBTROPICS.
}

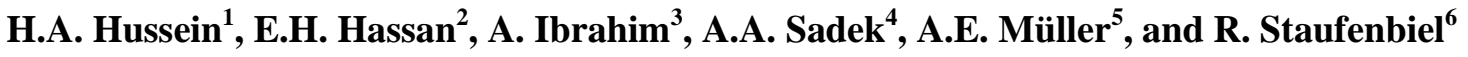 \\ ${ }^{1}$ Internal Veterinary Medicine, Department of Animal Medicine, Faculty of Veterinary Medicine, \\ Assiut University, Assiut 71526, Egypt. \\ ${ }^{2}$ Animal Production Department, Faculty of Agriculture, Al-Azhar University, Assiut, Egypt . \\ ${ }^{3}$ Veterinary Teaching Hospital, Faculty ofVeterinary Medicine, Assiut University, Assiut 71526, Egypt. \\ ${ }^{4}$ Department of Animal Surgery, Anesthesiology, and Radiology, Faculty of Veterinary Medicine, \\ Assiut University, Assiut 71526, Egypt. \\ ${ }^{5}$ Vet Med Labor GmbH, IDEXX Laboratories, Ludwigsburg, Germany \\ ${ }^{6}$ Klinik für Klauentiere der Freien Universität Berlin, Germany.
}

(Received 13/5/2021, accepted 9/7/2021)

\section{SUMMARY}

\begin{abstract}
$\mathrm{T}$ his study was conducted to evaluate some blood parameters, serum minerals profile and rumen liquor properties in dairy cows with foreign body syndrome and healthy ones. The present work was conducted as a retrospective cohort study for the cases admitted to Veterinary Teaching Hospital, Assiut University. Based on clinical, radiographic, ultrasonographic and post-operative findings, A total number of 37 dairy cows were classified into 3 groups, healthy dairy cows as a control $(n=10)$, cows with metallic foreign bodies $(n=15)$ and cows with non-metallic foreign bodies $(n=12)$. Blood samples were collected from each animal to determine some hematology, biochemical parameters and some minerals of serum. Rumen liquor samples were collected once from each cow, at the surgery to measure the rumen $\mathrm{pH}, \mathrm{NH} 3-\mathrm{N}$, total VFAs and total protozoa count. The results revealed no significant variations in hematological and biochemical indices among diseased groups as compared with control one. Serum concentrations of $\mathrm{Mg}$ and $\mathrm{Fe}$ were decreased $(\mathrm{P}<0.05)$ in dairy cows with metallic and non-metallic foreign bodies. The concentrations of $\mathrm{Cu}$ and $\mathrm{Zn}$ were decreased $(\mathrm{P}<0.05)$ in cows with metallic foreign bodies as compared with non-metallic foreign group and healthy dairy cows. Serum concentrations of $\mathrm{Mg}$ and $\mathrm{Fe}$ were decreased $(\mathrm{P}<0.05)$ in dairy cows with metallic and non-metallic foreign. The concentrations of $\mathrm{Cu}$ and $\mathrm{Zn}$ decreased $(\mathrm{P}<0.05)$ in cows with metallic foreign bodies as compared with non-metallic foreign group and healthy dairy cows. There was a decrease $(\mathrm{P}<0.05)$ in the rumen $\mathrm{pH}, \mathrm{NH}_{3}-\mathrm{N}$ and total protozoa count in diseased cows when compared with healthy cows. However, the total VFAs was higher $(\mathrm{P}<0.05)$ in diseased cows than control one. In conclusion, some blood constants, serum minerals profiles and rumen fermentation properties were greatly disturbed in dairy cows with foreign body syndrome. Therefore, mineral therapy may be recommended alongside surgical management of diseased cows and buffaloes with foreign body syndrome.
\end{abstract}

Keywords: Cows, blood parameters, serum minerals profiles ,rumen fermentation properties ,foreign body syndrome

\section{INTRODUCTION}

Foreign body syndrome is the condition which results from accidental eating of foreign materials. Ingestion of foreign bodies is common in ruminants because of a general lack of alimentary finesse, particularly in bovines (Constable et al. 2017). It could be caused by ingestion of metallic objects (nails, wire, needles), or non-metallic foreign bodies (ropes, clothes, plastics) (Sharma and Kumar 2006). Foreign body ingestion has emerged out as a major problem affecting the productivity of dairy animals (Constable et al., 2017). This syndrome may lead to several economic losses including reduced milk and 


\section{Hussein et al.}

mead productions, and costs of therapy, as well as potential deaths as a result of traumatic pericarditis may develop (Hussein and Staufenbiel 2014; Smith 2015 and Hussein et al. 2017).

The defect on rumen properties was a result of ruminal impaction due to plastic materials was asymptomatic and was diagnosed only after the accumulation of huge quantities of plastic materials in rumen (Vanitha et al., 2010). Anumber of factors have been implicated as risk factors for ingestion and accumulation of indigestible foreign materials in the rumen of cows. These include starvation during long periods of feed scarcity (Igbokwe et al., 2003), mineral and nutritional deficiencies (Radostitis et al., 2009), depraved appetite (Radostitis et al.,2009 and Vijaya et al., 2012) and increased environmental pollution with non-biodegradable materials, which prevail in the developing world (Ghurashi et al., 2009).

Minor and major minerals are essential elements required by animals. They act as antioxidants by neutralization of oxidants' effects (Andrieu 2008). In addition, trace elements also contribute to health of animals through keeping proper homostatic mechanisms and playing an important role in many physiological processes including protein, enzyme and hormone synthesis (Predieri et al. 2003). Calcium $(\mathrm{Ca})$, inorganic phosphorous $(\mathrm{P})$, magnesium $(\mathrm{Mg})$, copper $(\mathrm{Cu})$, iron $(\mathrm{Fe})$, and zinc $(\mathrm{Zn})$ are essential minerals required by humans and animals (Abdelrahman et al. 1998). Recent studies have focused on the role of minerals in disease resistance in dairy cows(Al-Qudah et al. 2010 and Ceylan et al. 2008), but little is known about the concentrations of $\mathrm{Ca}, \mathrm{P}, \mathrm{Mg}, \mathrm{Cu}, \mathrm{Fe}$, and $\mathrm{Zn}$ in bovine with foreign body syndrome. The present study was designed to evaluate of clinical, some blood parameters, serum minerals profile and rumen liquor properties in dairy cows with foreign body syndrome and healthy ones.

\section{MATERALS AND METHOAS}

\section{Animals, diets and management:}

A total number of 37 dairy cows were included in the current research study. This work was conducted as retrospective cohort study for the cases admitted to the Veterinary Teaching Hospital, Assiut University during the period extending from April 2016 to March 2018. Based on clinical radiographic, ultra-sonographic and post-operative findings, animals were classified into 3 groups as healthy dairy cows $(n=10)$, cows with metallic foreign bodies $(n=15)$ and cows with non-metallic foreign bodies $(n=12)$. All animals were fed a standard herd ration, which consisted of Berseem hay, wheat straw, and concentrate feed mixture. Ingredients' composition and chemical analysis of the concentrate mixture are shown in Tables (1) and (2). The chemical analysis of feeds was carried out using the procedures of AOAC ( 2005). The feeding value expressed as total digestible nutrient (TDN), were calculated using the chemical analyses of used ingredients and the apparent digestibility rates of different nutrients in the consumed diets according to McDonald et al. (1988). Metabolic energy (ME) were calculated according to Maaf. (1975) as following: $\mathrm{ME}(\mathrm{MJ} / \mathrm{Kg} \mathrm{DM})=\mathrm{DE}$ X 0.82. using duplicate samples.

Table (1) :Ingredients composition (\%) of the concentrate mixture of animals' ration.

\begin{tabular}{lc}
\hline Item & $(\%)$ \\
\hline${ }^{1}$ Concentrate feed mixture ${ }^{1}$ & 71 \\
Wheat bran & 25 \\
Limestone & 2 \\
Salt & 1 \\
Minerals Mixture & 1 \\
Total & 100 \\
\hline
\end{tabular}

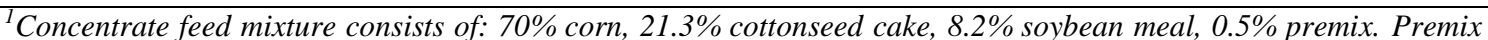
each $5 \mathrm{~kg}$ contain 1,250,000 IU vitamin A; 2,500,000 IU vitamin $D_{3} ; 1000 \mathrm{mg}$ vitamin E; 80,000 mg Mn; 60,000 mg $\mathrm{Zn}$; 50,000 mg iron; 20,000 mg copper; $5000 \mathrm{mg}$ iodine; $250 \mathrm{mg} \mathrm{Se} ; 1000 \mathrm{mg}$ Co until $5 \mathrm{~kg} \mathrm{CaCO}$.

In feeds $\mathrm{Ca}, \mathrm{P}, \mathrm{Mg}, \mathrm{Cu}, \mathrm{Zn}$, and $\mathrm{Fe}$ were determined using the Inductive Coupled Plasma Atomic Emission Spectroscopy (iCAP 6200) after digestion of samples using nitric acid. The diet was formulated 
(Table 2) according to the recommendations of N R C (2001) for dairy cows using body weight (600 kg) and milk production $(20 \mathrm{~kg}$ ) data. Animals were fed twice daily at 08.00 and $17.00 \mathrm{~h}$, and had free access to water all the day. After clinical, radiological and ultrasonographical examinations, control animals were free from foreign body syndrome.

\section{Blood sampling:}

From each animal, blood samples were obtained from the jugular vein .Each blood sample was divided into two parts. The first part was placed in tubes containing ethylene diamine tetraacetic acid (EDTA) for haematology. The other part was put in tube for separation of serum for determines the biochemical parameters. Samples were directly centrifuged at $3000 \mathrm{rpm}$ for $15 \mathrm{~min}$ and the serum was recovered and stored at $-20{ }^{\circ} \mathrm{C}$ in Eppendorf tubes until analysis. Non-coagulated blood was tested shortly after collection for estimating blood picture. All of the blood hematology and serum biochemistry were performed using standard protocols.

Table (2): Chemical composition of composition of the concentrate mixture (as fed).

\begin{tabular}{|l|c|}
\hline Items & Concentrate mixture \\
\hline Dry matter $(\%)$ & 91.50 \\
\hline Organic matter $(\%)$ & 89.00 \\
\hline Crude protein $(\%)$ & 15.80 \\
\hline Crude fiber $(\%)$ & 17.00 \\
\hline Ether extract $(\%)$ & 2.20 \\
\hline Nitrogen free extract (\%) & 54.00 \\
\hline Ash $(\%)$ & 11.00 \\
\hline Minerals $(\mathrm{mg} / \mathrm{kg}$, as feed) & \\
\hline $\mathrm{Ca}$ & 12634.41 \\
\hline $\mathrm{Mg}$ & 2501.47 \\
\hline $\mathrm{P} \mathrm{Cu}$ & 8809.41 \\
\hline $\mathrm{Cu}$ & 25.94 \\
\hline Fe & 458.46 \\
\hline $\mathrm{Zn}$ & 85.39 \\
\hline Total digestible nutrient $(\mathrm{TDN}) *$ & 66.42 \\
\hline Metabolizable energy $(\mathrm{Mcal} / \mathrm{kg}$ feed $) * *$ & 2.40 \\
\hline$* T D N=C P \times l+C F \times 1+(E E \times 2.25)$ & \\
\hline$* * M E M J / K g D M=D E X 0.82$. & \\
\hline
\end{tabular}

\section{Haematological parameters:}

The hematological parameters were assessed by using automatic, fully Digital Hematology Analyzer (Shenzhen Mind ray Auto Haematology Analyser (Model Bc-3200, Shenzhen Mind ray Biomedical Electronics Co. Hamburg 20,537, Germany). These parameters included a total count of white blood cells (WBC's), the total count of red blood cells (RBC's), hemoglobin $(\mathrm{g} / \mathrm{dl}, \mathrm{Hb})$ and hematocrit.

\section{Blood constituents:}

Serum total proteins and albumin concentrations were measured according to guidelines and recommendation of Bogin and Keller (1987). Globulin values were obtained by subtracting albumin values from the corresponding values of total protein. Serum total protein and albumin were assayed using special kits delivered from Spectrudiagnostics.com, MDSS GmbH, Schiffgraban 41, 30175, Hannover, Germany. Serum creatinine, AST and ALT were determined using test kits according to the method described by Baure (1982). Serum concentrations of $\mathrm{Ca}, \mathrm{P}, \mathrm{Mg}, \mathrm{Cu}, \mathrm{Fe}$, and $\mathrm{Zn}$ were determined by commercial test kits using a UV Spectrophotometer (Spectro UV-Vis, USA) according to the instructions of the manufacturers.

\section{Rumen liquor parameters:}

Rumen content samples were collected once from each cow, at the surgery. Rumen liquor samples were divided into two parts, the first part was filtered through one layer of cheese-cloth, which was used to measure the protozoa count. The total protozoa count was conducted according to Abou El-Naga 


\section{Hussein et al.}

(1967). However, the second part was filtered through four layers of cheese-cloth. The filtrated portion was used immediately for measure of $\mathrm{pH}$ using a digital $\mathrm{pH}$ meter. Ammonia $\mathrm{N}$ concentration was measured according to Conway (1962) method. Few drops of saturated solution of mercuric chloride were added to the filtrate to stop the microbial activity before its storage for analysis, and then the samples were kept frozen at $-20^{\circ} \mathrm{C}$ for determination of total volatile fatty acids (VFA,s). The total VFA,s acids were measured using the procedures of Warner (1964).

\section{Statistical analysis:}

Statistical analysis was done according to general linear model (G L M) of S A S (2001). Differences among groups for blood parameters and rumen liquor parameters were evaluated by one-way ANOVA. Duncan Multiple Range Test (Steel and Torrie, 1980) was used to test the effect of treatments. The data were presented as mean \pm S.E. Level of significance was set at $\mathrm{P}<0.05$. The statistical model was as follows:

$$
\mathrm{Y}_{\mathrm{ij}}=\mu+\mathrm{T}_{\mathrm{i}}+\mathrm{e}_{\mathrm{ij}}
$$

Where: $Y_{i j}=$ the observation $i j, \mu=$ the overall mean, $T_{i}=$ the effect due to treatment $i ., e_{i j}=$ the experimental error.

\section{RESULTS AND DISCUSSION}

\section{Clinical diagnosis:}

The following figure shows post-operative findings in cows with foreign body syndrome. Metallic foreign bodies were in the form of nails and wires (A), and non-metallic object as rubber bags and plastics

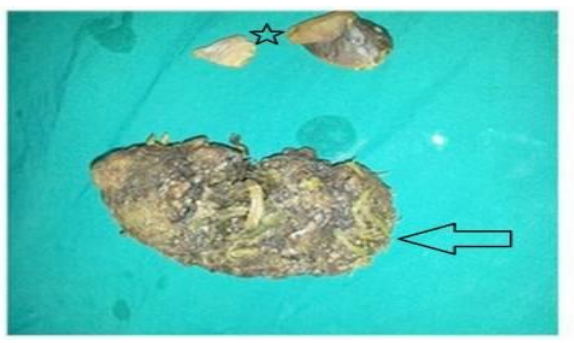

8

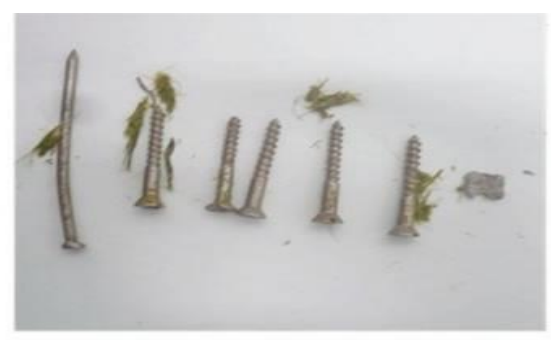

Fig. (1). Foreign body syndrome in cows.

Clinically, diseased animals were depressed and anorexic. Some cases showed cessation of rumination, ruminal atony, reduced dung frequency, and pain expression during movement.

\section{Post-operative findings:}

In dairy cows with metallic foreign bodies, some cases showed reticulitis, and local peritonitis and adhesions around the reticular wall, indicating penetration of reticulum by the sharp foreign bodies, however, in all cases the diaphragm was intact without penetrations. Rubber bags, ropes and stones with different shapes and sizes were retrieved as non-metallic foreign bodies post-operatively from diseased animals. The rumen and reticulum were found filled with plastic and rubber bags, and huge amount of undigested feeds, indicating indigestion.

Foreign body syndrome is becoming an emerging problem to bovine owners and farmers. It is greatly attributed to heavy industrialization and human habitation which has increase the chance of animals to ingest accidentally such objects (Sharma and Kumar 2006). In previous reports (Davenport et al, 1990 and Aytekin and Kalinbacak, 2008), the authors had incriminated this syndrome to many reasons including dietary protein deficiency, unbalanced dietary $\mathrm{Ca}-\mathrm{P}$ ratio, and $\mathrm{P}$ deficiency. Furthermore, Nugusu et al. (2013) reported that lacking cows and buffaloes to discriminate the diet, as well as insufficient feeding may force the animal to eat indigestible foreign materials. Foreign body syndrome may lead to serious complications including sudden death, poly bezoars, traumatic reticulo-pericarditis, 
immuno-suppression, bloat, indigestion, loss of condition and other unidentified health risks (Mohammed and Fromsa 2011, Abdelaal and El-Maghawry, 2014 and Tyasi et al. 2015).

\section{Blood constituents:}

The blood constituents were displayed in Table (3). Blood constituents are crucial tools for general health state and vitality. In this study, it was noticed that the finding metallic and non-metallic foreign bodies in the rumen of cows had no significant changes in all hematological parameters except WBC showed significant increase in cattle with metallic foreign bodies when compared with healthy cows. In addition, the average values of all biochemical indices revealed no significant variations except the serum values of total proteins and globulins were higher in cattle with metallic foreign bodies $(\mathrm{P}<0.05)$ than control once. However, the $\mathrm{A} / \mathrm{G}$ ratio was increased $(\mathrm{P}<0.05)$ in cattle with metallic foreign bodies as compared with control group. Other biochemical parameters such as total protein, AST, ALT and creatinine showed no significant changes.

The increase in WBCs in diseased groups of cows may be due to the stress reaction caused by inflammation (Blood and Radostits, 1994).Reddy et al.(2004) and Braun et al.(2007) attributed the changes in hematological findings might be due to the penetration of the reticulum or chronic inflammatory process in diseased cows. Despite the erythrogram indices showed no significant changes, pale mucous membranes observed in some diseased animals implanted with higher quantities of plastic bags may be due to interference with rumen microbial activity and mineral imbalance, thus, influencing vitamin B12 production, which could affect hemoglobin production and result in anaemia (Otsyina et al., 2017). The present results are in disagreement with those reported by Abdelaal and El-Maghawry (2014), who found that the diseased goats showed significant reduction in RBCs count, HB content, PCV and albumin when compared with control group. Similar results were obtained by Akinrinmade and Akinrinde (2012) in goats and Meyer et al. (1992) in cattle. This observation may be due to inadequate dietary intake or reduced absorption as a result of presence of foreign materials in the rumen.

Table (3): Hematological and biochemical differences between healthy and foreign body impacted cows.

\begin{tabular}{lcccc}
\hline & \multicolumn{3}{c}{ Treatment } \\
\cline { 2 - 4 } Item & Healthy cows & $\begin{array}{c}\text { Metallic foreign } \\
\text { bodies }\end{array}$ & $\begin{array}{c}\text { Non-metallic } \\
\text { foreign bodies }\end{array}$ & P-value \\
\hline $\mathrm{RBC}\left(\mathrm{x} 10^{6} / \mathrm{mL}\right)$ & $7.40 \pm 0.23$ & $6.95 \pm 0.15$ & $7.55 \pm 0.15$ & 0.845 \\
$\mathrm{Hb}$ g/dl & $10.57 \pm 0.27$ & $10.57 \pm 0.24$ & $11.04 \pm 0.20$ & 0.457 \\
Hematocrit \% & $31.8 \pm 0.65$ & $32.94 \pm 0.74$ & $31.57 \pm 0.90$ & 0.361 \\
WBC $\left(\times 10^{9} / \mathrm{L}\right)$ & $5.81^{\mathrm{b}} \pm 0.21$ & $7.95^{\mathrm{a}} \pm 0.15$ & $6.20^{\mathrm{b}} \pm 0.17$ & 0.001 \\
Total Protein mg/dl & $6.78^{\mathrm{b}} \pm 0.08$ & $8.77^{\mathrm{a}} \pm 0.06$ & $6.97^{\mathrm{b}} \pm 0.08$ & 0.001 \\
Albumin mg/dl & $3.58 \pm 0.06$ & $3.55 \pm 0.09$ & $3.53 \pm 0.09$ & 0.654 \\
Globulin mg/dl & $3.20^{\mathrm{b}} \pm 0.07$ & $5.22^{\mathrm{a}} \pm 0.13$ & $3.44^{\mathrm{b}} \pm 0.14$ & 0.001 \\
Al/Glo ratio & $1.1^{\mathrm{a}} \pm 0.04$ & $0.68^{\mathrm{b}} \pm 0.05$ & $1.03^{\mathrm{a}} \pm 0.05$ & 0.001 \\
AST U/L & $80.74 \pm 0.68$ & $79.22 \pm 0.54$ & $79.23 \pm 0.67$ & 0.187 \\
ALT U/L & $30.34 \pm 0.71$ & $29.40 \pm 0.79$ & $30.04 \pm 0.80$ & 0.685 \\
Creatinine $\mu \mathrm{mol} / \mathrm{L}$ & $77.28 \pm 0.63$ & $76.85 \pm 0.27$ & $77.56 \pm 0.41$ & 0.459 \\
\hline
\end{tabular}

Means within the same row with different superscripts differ significantly $(P<0.05)$.

\section{Serum minerals:}

Table (4) shows the serum concentrations of $\mathrm{Ca}, \mathrm{P}, \mathrm{Mg}, \mathrm{Cu}, \mathrm{Fe}$, and $\mathrm{Zn}$ in different animal groups. Calcium and phosphorus concentrations showed non-significant $(\mathrm{P}<0.05)$ changes among the different diseased groups and their corresponding healthy animals.Mg concentrations were significantly $(\mathrm{P}<0.05)$ decreased in cows with metallic and non-metallic foreign body syndrome. Compared with control the concentrations of $\mathrm{Cu}$ and $\mathrm{Zn}$ were significantly $(\mathrm{P}<0.05)$ decreased in cows with metallic foreign bodies as compared with non-metallic foreign group and healthy dairy cows. However, the Fe levels were found to be significantly $(\mathrm{P}<0.05)$ lower in dairy cows with metallic and non-metallic foreign body syndrome than healthy dairy cows. 


\section{Hussein et al.}

In the current study, serum concentrations of $\mathrm{Mg}$ were decreased in dairy cows with metallic and nonmetallic foreign body syndrome, the values remained within the reference range (Kaneko et al, 2008). As reported elsewhere (Yokus and Cakir, 2006), seasonal and physiologic variations must be taken intoconsideration for the correct interpretation of minerals status in cattle.

The serum concentrations of $\mathrm{Cu}, \mathrm{Fe}$, and $\mathrm{Zn}$ were decreased in dairy cows with foreign body syndrome. Such drop was higher extent in animals with metallic foreign bodies than non-metallic foreign bodies. This decrease may be attributed to impairment of these minerals absorption from gastrointestinal tract as a result of indigestion. In a previous study, Athar et al, (2010), concluded that the ingested foreign bodies (wires, ropes, plastics) may hinder the process of ruminal fermentation and interfere with mixing of the ingesta leading to indigestion and consequently failure of feed utilization. In addition, presence of foreign bodies in the rumen and reticulum may hamper the absorption of essential feed elements and volatile fatty acids (Igbokwe et al, 2003). Furthermore, despite the feed analysis, results for the concentrations of $\mathrm{P}, \mathrm{Mg}, \mathrm{Cu}, \mathrm{Fe}$, and $\mathrm{Zn}$ were within the recommended levels of dairy cows, their serum values were lowered in diseased animals.

Tables (4): Serum minerals of cows with foreign body syndrome and healthy ones.

\begin{tabular}{lcccc}
\hline & \multicolumn{3}{c}{ Treatment } \\
\cline { 2 - 4 } Item & Healthy cows & $\begin{array}{c}\text { Metallic foreign } \\
\text { bodies }\end{array}$ & $\begin{array}{c}\text { Non-metallic } \\
\text { foreign bodies }\end{array}$ & P-value \\
\hline $\mathrm{Ca}(\mathrm{mmol} / \mathrm{L})$ & $2.5 \pm 0.01$ & $2.4 \pm 0.02$ & $2.5 \pm 0.01$ & 0.176 \\
$\mathrm{P}(\mathrm{mmol} / \mathrm{L})$ & $1.9 \pm 0.01$ & $1.8 \pm 0.03$ & $1.8 \pm 0.03$ & 0.145 \\
$\mathrm{Mg}(\mathrm{mmol} / \mathrm{L})$ & $1.2^{\mathrm{a}} \pm 0.01$ & $0.9^{\mathrm{b}} \pm 0.01$ & $1.0^{\mathrm{b}} \pm 0.02$ & 0.001 \\
$\mathrm{Cu}(\mu \mathrm{mol} / \mathrm{L})$ & $14.6^{\mathrm{a}} \pm 1.01$ & $9.6^{\mathrm{b}} \pm 1.01$ & $13.1^{\mathrm{a}} \pm 1.06$ & 0.001 \\
$\mathrm{Fe}(\mu \mathrm{mol} / \mathrm{L})$ & $20.4^{\mathrm{a}} \pm 1.03$ & $11.8^{\mathrm{b}} \pm 1.07$ & $11.7^{\mathrm{b}} \pm 0.04$ & 0.001 \\
$\mathrm{Zn}(\mu \mathrm{mol} / \mathrm{L})$ & $15.8^{\mathrm{a}} \pm 0.09$ & $10.1^{\mathrm{b}} \pm 1.04$ & $14.7^{\mathrm{a}} \pm 1.04$ & 0.001 \\
\hline \multicolumn{2}{l}{ Means within row bearing different superscripts differ significantly $(P<0.05)}$. & &
\end{tabular}

\section{Rumen properties:}

The rumen fermentation parameters were exhibited in Table (5).There was a significant $(\mathrm{p}<0.05)$ decrease in the rumen $\mathrm{pH}, \mathrm{NH} 3-\mathrm{N}$ and total protozoa count in diseased cows when compared with healthy cows. However, the total VFAs was higher $(\mathrm{P}<0.05)$ in dairy cows with metallic and non-metallic foreign body syndrome than healthy cows. The cows with non-metallic foreign bodies were lower $(\mathrm{p}<0.05)$ in $\mathrm{pH}$ and total protozoa count than cows with metallic foreign bodies.

Table (5): Effect of foreign body syndrome on rumen fermentation parameters.

\begin{tabular}{lcccc}
\hline & \multicolumn{3}{c}{ Treatment } & P-value \\
\cline { 2 - 4 } Item & Healthy cows & $\begin{array}{c}\text { Metallic foreign } \\
\text { bodies }\end{array}$ & $\begin{array}{c}\text { Non-metallic } \\
\text { foreign bodies }\end{array}$ & Poinnnnnn 0.001 \\
\hline $\mathrm{pH}$ & $6.80^{\mathrm{a}} \pm 0.06$ & $5.63^{\mathrm{b}} \pm 0.09$ & $5.23^{\mathrm{c}} \pm 0.03$ & 0.001 \\
$\mathrm{NH} 3-\mathrm{N}, \mathrm{mg} / \mathrm{dl}$ & $15.09^{\mathrm{a}} \pm 0.30$ & $11.76^{\mathrm{b}} \pm 0.29$ & $11.42^{\mathrm{b}} \pm 0.26$ & 0.001 \\
Total VFAs, $\mathrm{m} M$ & $71.01^{\mathrm{c}} \pm 0.33$ & $76.24^{\mathrm{b}} \pm 0.37$ & $81.04^{\mathrm{a}} \pm 0.76$ & 0.001 \\
Total protozoa count, $\times 10^{6} / \mathrm{ml}$ & $5.23^{\mathrm{a}} \pm 0.18$ & $4.04^{\mathrm{b}} \pm 0.14$ & $3.36^{\mathrm{c}} \pm 0.08$ & 0.14 \\
\hline
\end{tabular}

Means within row bearing different superscripts differ significantly $(P<0.05)$.Conclusion.

From the results of this study we can notice a defect in rumen fermentation with metallic and nonmetallic bodies in rumen of cattle's. Presence of foreign body inside the rumen gives a picture of subacute ruminal acidosis leading to reduction of $\mathrm{pH}$ (Bakhiet, 2008). These results are in agreement with those reported by Abdelaal and El-Maghawry (2014) who revealed that goats with foreign body were significant decrease in ruminal $\mathrm{pH}$ and prolonged Methylene blue reduction time as compared with healthy goats. The lower ammonia concentration in rumen fluid may be attributed to lack of digestion of feed inside the rumen due to metallic and non-metallic bodies in the rumen. Radostits et al, (2007) and Vanitha et al, (2010) confirmed that the presence of impacted material may cause, partially or completely, block of the rumino-reticular orifices. The ingested polythene hinders the process of fermentation and mixing of contents might lead to indigestion. The higher value of total VFA's in the rumen particularly 
with Non-metallic foreign bodies group may be due to the physical presence of metallic and plastic foreign bodies in rumen and reticulum that interferes with the absorption of volatile fatty acids in rumen and reticulum and leads to the accumulation of fatty acids in the rumen .There by, may hamper the milk yield and the rate of animal fattening (Tyagi and Singh, 2004 and Sheferaw et al., 2014). When the process of fermentation and absorption of volatile fatty acids is interfered with as a result of accumulation of indigestible foreign bodies in the rumen, the animal is deprived of valuable nutrients for its survival (Igbokwe, 2003). It could be noticed that the total protozoa count was decreased with the presence of foreign bodies in rumen, especially with non-metallic bodies group. In this context, Radostitis et al.(2009) reported that the presence of plastic bags in the rumen may have hindered effective fermentation and functioning of the rumen microflora. Similarly, Randall et al. (2002) sated that the presence of foreign bodies inside the rumen of sheep lead to reduction of fermentable ingesta in the rumen and possible disturbances in microbial fermentation and reduced fatty acid production and absorption.

\section{CONCLUSION}

The blood constants, serum minerals profiles and rumen fermentation properties are greatly disturbed in dairy cows with foreign body syndrome. Therefore, mineral therapy may be recommended alongside surgical management of diseased cows and buffaloes with foreign body syndrome.

\section{REFRENCES}

Abdelaal, A.M. and S ,EL-Maghawry (2014). Selected studies on foreign body impaction in goats with special reference to ultrasonography, VeterinaryWorld. 7(7): 522-527.

Abdelrahman, M., R., Kincaid, and E.A. Elzubeir, (1998). Mineral deficiencies in grazing dairy cattle in Kordofan and Darfur regions in western Sudan. Tropical Animal Health Production 30:123-135

Abou El-Naga M.,( 1967). Some metabolic studies on rumen microorganisms. M.Sc. Thesis, Fac. of Agric., Univ. of Alexandria, Egypt.

Akinrinmade, J.F. and A.S. Akinrinde, (2012). Hematological and serum biochemical indices of West African Dwarf goats with foreign body rumen impaction. Nig. J. Physiol. Sci., 27(1): 83-87.

Al-Qudah, K., A., Gharaibeh, and M. Al-Shyab, (2010). Trace minerals status and antioxidant enzymes activities in calves with dermatophytosis. Biol Trace Elem Res. 136: 40-47.

Andrieu, S. (2008). Is there a role for organic trace element supplements in transition cow health. Vet. J .176: 77-83.

AOAC. ( 2005 ). Association of Official Analytical Chemists . Official Methods of Analysis, 16th ed. Washington, DC, USA

Athar, H., J., Mohinderoo, K., Singh, A., Kumar, and M. Raghunath, (2010). Comparison of Radiography and Ultrasonography for diagnosis of diaphragmatic Hernia in Bovines. Veterinary medicine International doi:10.4061/2010/939870.

Aytekin, I., and A. Kalinbacak, (2008). The levels of calcium, phosphor, magnesium, copper, zinc and iron in calves eating soil in the region of Afyon. Atatürk Univ. J .Vet. Sci 3: 34-42.

Bakhiet, O.A. (2008) Studies on the rumen pathology of Sudanese desert sheep in slaughter house. Sci Res Essays, 3: 294-298.

Baure, J.D. (1982). Clinical laboratory Methods Mosby, C V.USA, 9th Ed. p496, 1121.

Blood DC, and O.M Radostits, (1994). Veterinary Medicine, A Text Book of the Diseases of Cattle, Sheep, Pigs, Goats and Horses, 8th ed. Bailliere Tindall, pp: 265-272. 


\section{Hussein et al.}

Bogin, E. and P. Keller,( 1987). Application of clinical biochemistry to medically relevant animal models and standardization and quality control in animal biochemistry. Journal of Clinical Chemistry and Biochemistry, 25: 873-878

Braun .U, G,Schewizer and B. Legune, (2007). Clinical findings of cattle with traumatic pericarditis. Vet. Rec., 161: 558-563.

Ceylan, A., L., Sern, and H. Akst, et al. (2008). Concentrations of some elements in dairy cows with reproductive disorders. Bull Vet Inst Pulawy, 52: 109-112.

Constable, P.D., K.W., Hinchcliff, and S.H. Done, et al. (2017). Chapter 8: Diseases of the alimentary tract-Ruminant. In: Veterinary medicine: A Textbook of the Diseases of Cattle, Horses, Sheep, Pigs, and Goats. $11^{\text {th }}$ edn, Elsevier, Missouri, USA, pp. 436-621.

Conway, EJ. (1964). Microdefusion Analysis and Volumetric Error. $5^{\text {th. }}$ Ed. Crosby- Lockwood and Sons Ltd., London.

Davenport, G.M., J.A ,Boling,.and N. Gay, (1990). Bioavailability of magnesium in beef cattle fed magnesium oxide or magnesium hydroxide, J. Anim .Sci. 68: 765-3772.

Ghurashi, M.A. H., H. I, Seri, A.H ,Bakheit, and , E.A.M. Ashwag, (2009). Effect of surgical removal of foreign body from goat's rumen with special reference to the prevalence of foreign body in goats in Southern Dafur. Australian Journal of Basic and Applied Science, 3(2): 664-668.

Hussein, H.A.,K.E.,Hanan, and E.O.Yasmin, (2017). Oxidative stress indices and pathological changes in cattle with traumatic pericarditis. J. Hellenic Vet. Med ,Soc 68: 579-586.

Hussein, H.A., Staufenbiel, R. 2014. Clinical presentation and ultrasonographic findings in buffaloes with congestive heart failure. Turk J Vet Anim Sci 38, 534-545.

Igbokwe, I.O., M.Y., Kolo, and Egwu, (2003). Rumen impaction in sheep with indigestible foreign body in the semi-arid G.O. region of Nigeria. Small Ruminant Research, 49: 141-147.

Kaneko, J.J., J.W., Harvey, and M.L. Bruss, (2008). Clinical biochemistry of domestic animals. Academic press, New York, USA, pp. 886.

Maaf, (1975). Ministry of agriculture, fisheries and food energy allowwwwances and feeding system for ruminants.Technical bulletin,99 London,H.M.50.

McDonalds, P., R.A., Edward, and J.F.D, Greenhalgh, (1988). Animal Nutrition (4th edition) Longman, U.K.

Meyer, Y., E.H, Coles,. and L.J. Rich, (1992). Veterinary Laboratory Medicine. Interpretation and Diagnosis. W.B. Saunders Co., Philadelphia,p 327-329

Mohammed, N., and A. Fromsa,(2011). Prevalence of iIndigestible foreign body ingestion in small ruminants slaughtered at Luna Export Abattoir, East Shoa, Ethopia. J. Anim. Vet Adv, 10: 15981602.

N R C ( 2001). Nutrient Requirements of Dairy Cattle. 7th rev. edn. Natl Acad Sci, Washington DC, pp. $15-48$.

Nugusu, S., , R., U, C, et al. (2013). Studies on Foreign Body Ingestion and their Related Complications in Ruminants Associated with Inappropriate Solid Waste Disposal in Gondar Town, North West Ethiopia. International Journal of Animal and Veterinary Advances 5: 67-74.

Otsyina, H. R., J. Nguhiu-Mwangi, M.o, Egm, P .G. Mbuthia, and W.O.Ogara, (2017). Clinical manifestations in sheep with plastic bags in the rumen. Ghana ,J. Sci. 57: 35-45

Predieri, G., M., Tegoni, and E. Cinti, et al.( 2003). Metal chelates of 2-hydroxy-4-methyl thiobutanoic acid in animal feeding: preliminary investigations on stability and bioavailability. J Inorg Biochem, 95: 221-224.

Radostitis, O.M., C.C., Gray, , D.C Blood and K.W. Hinchelift, (2009.) Veterinary Medicine: A Textbook of the Diseases of Cattle, Sheep, Pig, Goats and Horses, 10th edn New York,USA: Saunders Elsevier. Pp. 189-382, 296 and 313.

Radostits OM, CC, Gay ., KW Hinchcliff, and P.D Constable, (2007). Impaction of the omasum. Veterinary Medicine: A textbook of the Diseases of Cattle, Horses, Sheep, Pigs and Goats. 10th ed. Elsevier Health Sciences, Philadelphia, PA, UA, pp: 352-353. 
Randall, D., W. Burggren, and K.French, (2002). Eckert animal physiology: Mechanisms and adaptations. 5th ed. W.H. Freeman and Compan, New York, NY pp. 78- 93.

Reddy RY, TP, Naidu ST,Viroji and S.N Syama, (2004). Foreign bodies in rumen and reticulum of Punganur cattle. Indian. Vet. J. 81:1063.

SAS., (2001). SAS/ STAT Guide for personal computer .(version 8.2 nd. SAS. INST., Cary, N.C.

Sharma, M., and P. Kumar, (2006). Foreign body syndrome in Buffaloes (Bubalus bubalis): An Emerging Threat. Asian .J. Anim and Vet .Adv 1: 89-98.

Sheferaw , D., G., Fikreysus, A., Metenyelesh, T.Dawit, and D. Etana, (2014). Ingestion of indigestible foreign materials by free grazing ruminants in Amhara Region, Ethiopia. Trop. Anim. Health Prod., 46: $247-250$.

Smith, B. (2015). Large Animal Internal Medicine. 5 edn Mosby, USA.

Steel R.G. and J.H. Torrie, (1980). "Principles and Procedures of Statistics" A Biometrical Approach 2 nd Ed Mc Grow- Hill Book Co., New York.

Tyagi, R.P.S. and J. Singh, (2004) Ruminant Surgery. CBS Publishers and Distributors, New Delhi. p198-204.

Tyasi, T.L., M., Ngayo, and N. Qin,( 2015). The use of Nguni in crossbreeding programmes as a way to improve both the communal and commercial beef enterprises in South Africa. Afr. J. Agric Sci Technol, 3: 244-248.

Vanitha V, AP, Nambi . B, Gowri.,and S. Kavitha (2010). Rumen impaction in cattle with indigestible foreign bodies in Chennai. Tamilnadu J. Vet. Anim. Sci., 6: 138-140.

Vijaya, M., B. Reddy, and P. Sasikala, (2012). A review of foreign bodies with special reference to plastic pollution threat to livestock and environment in Tirupati rural areas. International Journal of Scientific and Research Publications, 2 (12): 1-8.

Warner, A.C.I., (1964). Production of volatile fatty acids in the rumen: methods of measurement. Nutrition Abstract Review, 34:339.

Yokus, B., U. Cakir, (2006). Seasonal and Physiological Variations in Serum Chemistry and Mineral Concentrations in Cattle. Biol Trace Elem Res ,109: 255-266. 


\section{Hussein et al.}

تقييم خصائص الام والمعادن في مصل الام وتخمرات الكرش فى الأبقار المصابة بظاهرة إبتلاع الأجسام الغريبة فى المناطق شبه الاستوائيه.

حسين عوض حسين1، إكرامي حامد صادق حسن، ، أحمد إبراهيم3، أحمد عبدالرحيم صادق4 ، أنيا-إليفيرا مولر5،

رودولف شتاوفينبيل6

1 $1{ }^{1}$

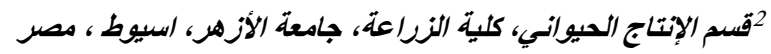

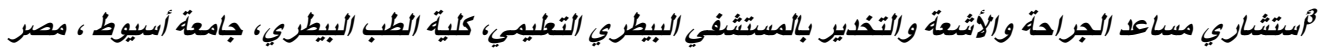

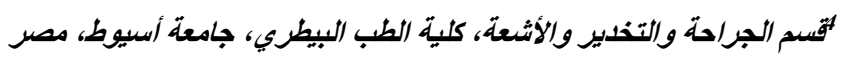

5 المعطل المرجعي للطب البيطري، لودفيجسبورج، ألمانيا

6 مستشفي المجترات، جامعة برلين الحرة، ألمانيا

أجريت هذه الدراسة لتقييم بعض خصائص الدم والعناصر المعدنية في مصل الدم وخصائص سائل الكرش في الابقار السليمه

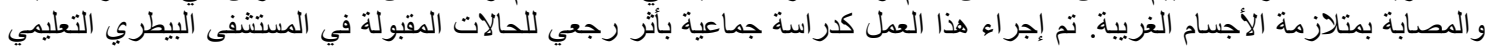

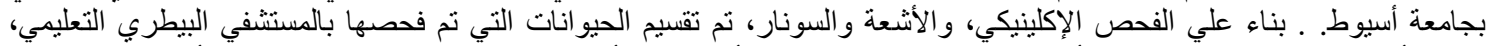

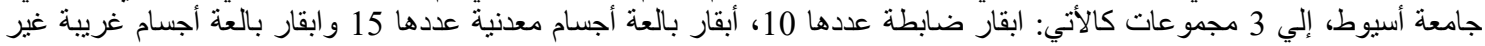

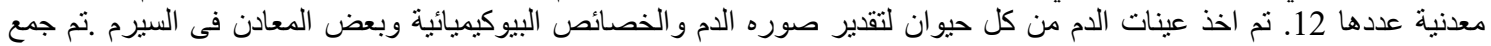

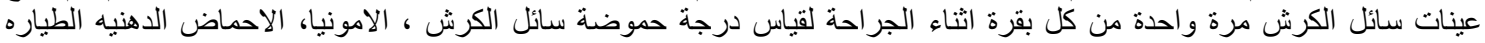

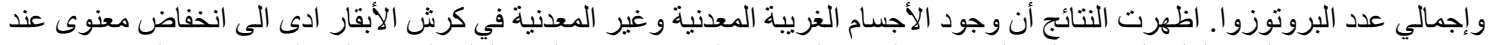

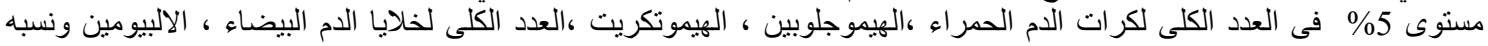

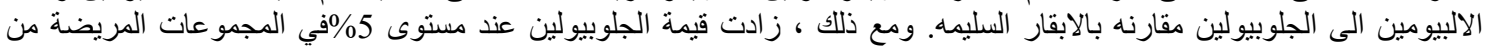

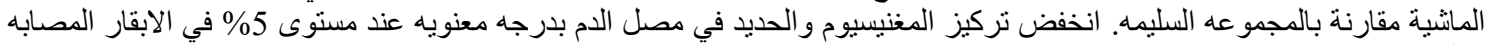

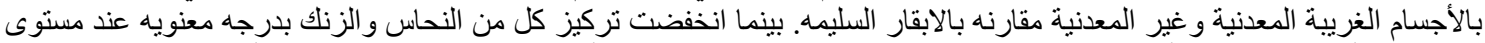

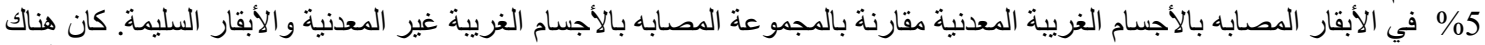

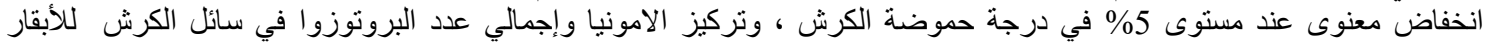

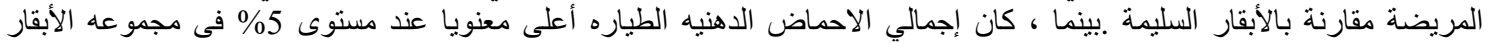

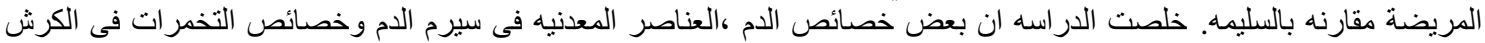

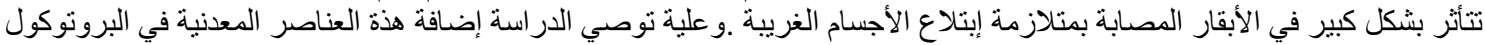
العلاجي للحيو انات المصابة بجانب العلاج الجراحي. 